\title{
Morphogenetic and Bioecological Characters of the Shirvan Plain Soils in the Azerbaijan Republic
}

\author{
Shahla Z. Jafarova
}

Institute of Soil Science and Agrochemistry, Baku, Azerbaijan.

Email: shahla.jafarova@yandex.ru

Received May $6^{\text {th }}, 2013$; revised June $6^{\text {th }}, 2013$; accepted June $15^{\text {th }}, 2013$

Copyright (C) 2013 Shahla Z. Jafarova. This is an open access article distributed under the Creative Commons Attribution License, which permits unrestricted use, distribution, and reproduction in any medium, provided the original work is properly cited.

\begin{abstract}
The economic, political and social stability of the society, and an efficiency of the agroindustrial complexes depend on state of the soil resources. Using of the soil resources rationally is an important term for provision of the food safety. In this regard what results are presented in this article by us is carried out for studying of morphogenetic and bioecological features of soils of the Shirvan steppe of the Azerbaijan Republic.
\end{abstract}

Keywords: Shirvan Steppe; Grey-Meadow Soils; Parameters of Fertility; Salinization

\section{Introduction}

In the regions of intensive agriculture and in the zones of the industrial production, high concentration on the antropogen loading in the soil became not only commensurable with the intensity of soil forming process but also increased it considerably. There is no doubt that both from ecological standpoint and from economical standpoint the prevention of the soil unfavorable changes are more expedient than fulfillment of costing dear works over their restoration. In the limits of the republic, especially in the zones of the intensive agriculture, the changeableness of soil-climatic, relief and other factors strongly influence on agricultural production, including on productivity of the agricultural farming lands and soil cover fertility. In this connection we have studied a contemporary soil-ecological condition of the Shirvan steppe soil cover, the territory which is distinguished by high degree of the appropriation and large development of the irrigative agriculture.

\section{Results and Discussion}

The Shirvan steppe becomes an inclined plain in the Kur left bank entering the Kur-Araz lowland content, and a total area of the steppe forms $7115 \mathrm{~km}^{2}$. The steppe is bordered by the river of Kur from the south-west and south, Bozdag from north-east foothill mountain range of the Great Caucasus, Langebiz mountain range from northeast, and Haramy range from east.

The soil cover of the investigative territory develops on delluvial, delluvial-prolivial and alluvial deposits [1] The soils of the Shirvan steppe are solonetzic and saline to some or order degree that is related with the material rocks. On relief the Shirvan divides on inclined plain and a round the Kur zone. The Shirvan steppe climate is semidesert subtropic. The average yearly temperature of the air is $14^{\circ} \mathrm{C}-15^{\circ} \mathrm{C}$, yearly evaporation is $912 \mathrm{~mm}$, and average yearly precipitations are $270-278 \mathrm{~mm}$. An influence of the climate is displayed in improvement of xerophytes vegetation, in the quick mineralization of organic substance and in combination with other ecological factors on soil cover formation.

The wormwood and cargano-wormwood vegetation is main vegetative formation developing in the Shirvan steppe. On the territory of the Shirvan steppe the soil investigations are conducted by the authors for different purposes $[1,2]$. Grey-meadow, meadow-grey and greybrown soils are predominant soils of the investigative territory. The indicating soil types are divided into subtypes: sorts and varieties in dependence with salinity degree, solonetzicity and leaching degree, mechanical composition, cultivation and thickness.

Grey-meadow soils being one of the spreading soils in the Shirvan steppe occupy covering trains, of ten depressive reductions, where for an important part of the year the conditions of the high subsoil humidity are preserved. In the grey-meadow soils the signs of the past hydrogen soilforming stages have been found. The high content firmly related with the mineral part of the soils organic substances is characteristic for them. The virgin versions 
of grey-meadow soil contain humus in the upper horizons in limits of $1.3 \%-2.0 \%$, under sorgo $0.95 \%$ $1.75 \%$, under lucerne $1.17 \%-1.57 \%$ [3]. The nitrogen content is also insignificant: under sorgo $0.08 \%-0.14 \%$, under Lucerne $0.10 \%-0.15 \%$.

An analysis of the mechanical composition in the investigative soils revealed characteristic difference between them. The mechanical composition of the greymeadow soils is very heavy with the content of the physical clay in different cenozes till $63 \%-80 \%$ unlike other investigative soils.

Unlike meadow-grey soils the grey-meadow soils are characterized by strong alkaline reactions $\mathrm{pH} 8.1-9.5$. Evidently the high solonitzicity and calcareous of these soils influenced on the environment reaction in the definite form. Both virgin and cultivating versions of these soils are distinguished by high alkalinity on the whole profile where $\mathrm{pH}$ reaches 8.7 - 9.4.

A quantity of easily dissolving salts in the grey-brown soils is less in the soils under sorgo than in the soils under lucerne and it vibrates by $0.16 \%-0.20 \%$ along the profile. But a quantity lucerne, it reduces towards low layers $-0.70 \%$ [4]. A quantity of carbonates is higher in the soils under sorgo than in the soils under lucerne in the greymeadow soils and it changes along the profile $13.53 \%$ 18.78\% (Table 1).

Meadow-grey soils are formed in the conditions of the highest subsoil humidity under bed of subsoil waters of $1-3$ $m$ [2]. A quantity of the subsoil humidity visibly influences on soil profile change, in development of the gleyey process. Enough subsoil humidity favour powerful development of vegetation, accumulation of the root remnants and humus. In the virgin soils under wormwood-ephemer communication a quantity of humus on upper layers reaches $1.86 \%$, humus reduction is observed till low layer $1.15 \%-0.57 \%$. A gradual falling of nitrogen quantity is observed from upper horizons 0.15 $\%$ to low $0.07 \%-0.11 \%$. The humus quantity in meadow-grey soils under lucerne forms $1.21 \%-1.65 \%$ on upper and $0.74 \%-0.95 \%$ on low horizons [5].

A mechanical composition of meadow-grey soils is lighter than grey-brown soils. A quantity of physical clay in the virgin soils forms $70.32 \%-52.60 \%$ on upper and middle horizons, but on deep layers $48.92 \%-24.88 \%$ (Table 1). Agrocenoz of lucerne are distinguished by evener distributions and relatively stable content of salty and clayey particles, though they slightly surpass virgin soils over content.

In the grey-brown soils the environment reaction is alkaline character, the parameter is 8.3 on upper layers, reduction is observed towards low horizons in comparison with grey-brown soils. The environment reaction remained stable $8.0-8.1$ over the horizons in the soils under lucerne in comparison with the virgin soils [6].
In the meadow-grey soils a quantity of dry residue is less $0.13 \%$ than in the soils under lucerne in the virgin soils, an increase is observed along the profile $0.37 \%$. A quantity of dry residue in the soils under lucerne is enough high, on upper layer it is $0.34 \%$, but increase is observed towards low layers $1.10 \%$ [7]. A quantity of carbonates in the meadow-grey soils was higher $13.83 \%$ and increase is observed towards low $18.45 \%$ (Table 1).

Grey-brown soils are characterized by more or less degree of differentiation. Prism-like layer testifying the solonetzicity availability is situated under humic layer [1]. The humus content in the virgin soil under worm-woodephemer vegetation on upper layers $0-5 \mathrm{~cm}$ and $5-22$ $\mathrm{cm}$ change in limits of $1.05 \%-1.36 \%$. On low layers it reaches $0.45 \%-0.64 \%$. The nitrogen content on upper horizons changes in analogical way $0.10 \%-0.12 \%$, on low layers it reduces till $0.06 \%-0.07 \%$. They greybrown soils under cereals are significantly distinguished from virgin soils over their quantitative parameters of humus and nitrogen.

In these soils, the humus content on upper layers reaches $1.52 \%-1.86 \%$, its quantity on the low horizons forms $1.21 \%-1.40 \%$. The nitrogen content on upper layers is $0.12 \%-0.15 \%$, but on low layers it forms $0.07 \%-0.11 \%$. The grey-brown soils are expressed by enough saturated salty and glayey particals. In the virgin soils on upper layer $(0-5 \mathrm{~cm})$ a minimal quantity contents $6.6 \%$, on middle layer $22-50 \mathrm{~cm}, 41.86 \%-35.42 \%$, near soil forming rocks $74-105 \mathrm{~cm}, 30.68 \%$. A quantity of physical clayey is analogically changed. In the greybrown soils under cereals a quantity of silty fraction practically was the same $38.84 \%-38.40 \%$ both on upper and on low horizons [8]. Evidently the agrotechnical measures promote over an even transformation of the salty fraction over the soil profile. At the same time the soil mechanical cultivation and irrigation resulted in formation of the significant mass of the physical clay.

While paying attention to the soil environment in the grey-brown soils we can see $\mathrm{pH}$-quantity in the virgin soils is higher than the soils growing under grain 8.3 and an increase of alkaline towards low layers is observed 8.5, $\mathrm{pH}$ quantity under irrigative undergrain is low 8.2 , a reduction towards below is observed $8.0-8.1$.

A quantity of dry residue in the soils under grain is lower along profile $0.24 \%-0.28 \%$ than the virgin version of grey-brown soils, but this parameter in the virgin soils is high $0.2 \%$, an increase is observed towards low layers $1.10 \%$. Carbonates quantity is little $2.65 \%$ on upper layer in the virgin version of the grey-brown soils, but a strong increase is observed towards low layers $13.97 \%$. But the carbonates quantity is the same along the profile $20.50 \%-21.84 \%$ in the grey-brown soils growing under grain. 
Table 1. Physico chemical parameters of the main soils in the Shirvan steppe under different cenozes.

\begin{tabular}{|c|c|c|c|c|c|c|c|c|c|c|c|}
\hline Soil cuts & $\begin{array}{l}\text { Horizons, } \\
\mathrm{cm}\end{array}$ & $\begin{array}{c}\text { Humus, } \\
\%\end{array}$ & $\begin{array}{c}\text { Azot, } \\
\%\end{array}$ & $\begin{array}{c}\mathrm{CaCO}_{3}, \\
\%\end{array}$ & $\begin{array}{c}\text { Arid } \\
\text { residue, } \\
\%\end{array}$ & $\mathrm{pH}$ & $\begin{array}{l}\text { Hygroscopic } \\
\text { humidity, \% }\end{array}$ & $\begin{array}{l}<0.001 \\
\mathrm{~cm}, \%\end{array}$ & $\begin{array}{l}<0.01 \\
\mathrm{~cm}, \%\end{array}$ & $\begin{array}{c}\mathrm{Ca}, \\
\text { mg-ekv }\end{array}$ & $\begin{array}{c}\mathrm{Mg}, \\
\text { mg-ekv }\end{array}$ \\
\hline \multirow[t]{2}{*}{ Grey-meadow: } & $0-27$ & 1.71 & 0.141 & 18.78 & 0.19 & 8.3 & 2.16 & 14.68 & 54.20 & 8.47 & 5.75 \\
\hline & $27-52$ & 0.95 & 0.094 & 17.20 & 0.20 & 8.4 & 1.96 & 7.12 & 31.24 & 8.36 & 2.17 \\
\hline \multirow[t]{4}{*}{ p-1 Sorgo } & $52-80$ & 0.84 & 0.087 & 13.53 & 0.17 & 8.5 & 2.51 & 19.76 & 64.71 & 7.28 & 6.40 \\
\hline & $80-112$ & 0.59 & 0.039 & 16.35 & 0.21 & 8.4 & 3.71 & 16.68 & 59.20 & 5.30 & 2.89 \\
\hline & $112-145$ & 0.52 & 0.035 & 18.53 & 0.16 & 8.3 & 2.28 & 6.84 & 36.76 & 4.51 & 3.05 \\
\hline & $0-30$ & 1.77 & 0.146 & 11.92 & 1.12 & 8.1 & 2.80 & 28.52 & 69.28 & 14.59 & 2.15 \\
\hline \multirow{4}{*}{ P-2 Lucerne } & $30-55$ & 1.67 & 0.133 & 12.68 & 0.96 & 8.4 & 2.42 & 33.12 & 81.20 & 8.82 & 6.84 \\
\hline & $55-82$ & 1.09 & 0.103 & 13.10 & 0.69 & 8.4 & 2.17 & 24.52 & 86.88 & 7.13 & 6.82 \\
\hline & $82-110$ & 0.64 & 0.075 & 11.36 & 0.59 & 8.4 & 2.05 & 18.84 & 78.56 & 5.12 & 9.28 \\
\hline & $110-138$ & 0.52 & 0.067 & 14.56 & 0.70 & 8.3 & 2.33 & 34.76 & 88.96 & 8.83 & 11.5 \\
\hline \multirow[t]{2}{*}{ Meadow-grey: } & $0-5$ & 1.86 & 0.15 & 10.70 & 0.13 & 8.3 & 4.02 & 27.44 & 70.32 & 13.26 & 2.56 \\
\hline & $5-22$ & 1.47 & 0.13 & 11.13 & 0.12 & 8.3 & 4.03 & 28.24 & 60.44 & 14.00 & 1.92 \\
\hline \multirow[t]{4}{*}{ P-3 Virgin soil } & $22-50$ & 1.26 & 0.12 & 14.56 & 0.20 & 8.4 & 3.43 & 18.64 & 52.60 & 13.26 & 2.75 \\
\hline & $50-75$ & 1.15 & 0.11 & 16.79 & 0.28 & 8.4 & 3.02 & 11.24 & 48.92 & 10.67 & 2.67 \\
\hline & $75-107$ & 0.58 & 0.07 & 18.10 & 0.37 & 8.0 & 2.85 & 5.20 & 24.88 & 17.40 & 7.90 \\
\hline & $0-22$ & 1.90 & 0.15 & 13.83 & 0.34 & 8.0 & 4.40 & 27.04 & 85.12 & 13.90 & 5.05 \\
\hline \multirow{8}{*}{ P-4 Lucerne } & $22-50$ & 1.65 & 0.14 & 13.83 & 0.67 & 8.1 & 4.42 & 29.64 & 80.00 & 15.20 & 3.11 \\
\hline & $50-77$ & 1.21 & 0.11 & 13.37 & 0.59 & 8.0 & 4.39 & 29.72 & 85.72 & 13.64 & 6.51 \\
\hline & $77-92$ & 0.90 & 0.10 & 16.95 & 0.80 & 7.9 & 4.53 & 22.24 & 84.04 & 16.95 & 6.23 \\
\hline & $92-100$ & 0.74 & 0.08 & 18.45 & 1.10 & 8.0 & 4.96 & 19.44 & 82.52 & 23.18 & 4.70 \\
\hline & $0-5$ & 1.36 & 0.12 & 2.65 & 0.208 & 8.3 & 2.65 & 6.60 & 36.92 & 6.02 & 2.82 \\
\hline & $5-22$ & 1.05 & 0.10 & 3.60 & 0.300 & 8.4 & 4.60 & 41.86 & 61.86 & 8.94 & 9.64 \\
\hline & $22-50$ & 0.64 & 0.07 & 20.69 & 0.392 & 8.4 & 4.90 & 35.52 & 60.88 & 6.92 & 8.35 \\
\hline & $50-74$ & 0.45 & 0.07 & 16.30 & 0.450 & 8.3 & 5.00 & 31.25 & 60.75 & 12.00 & 8.72 \\
\hline \multirow{6}{*}{ Grey-brown: } & $74-105$ & 0.31 & 0.06 & 13.97 & 1.502 & 8.5 & 5.10 & 30.68 & 61.16 & 15.83 & 8.92 \\
\hline & $0-22$ & 1.86 & 0.15 & 20.50 & 0.264 & 8.2 & 4.54 & 38.36 & 85.12 & 13.91 & 5.50 \\
\hline & $22-45$ & 1.52 & 0.13 & 20.50 & 0.280 & 8.3 & 4.42 & 35.16 & 80.00 & 13.45 & 9.09 \\
\hline & $45-70$ & 1.41 & 0.12 & 19.35 & 0.242 & 8.3 & 4.67 & 36.84 & 85.72 & 12.14 & 2.67 \\
\hline & $70-92$ & 1.21 & 0.11 & 21.84 & 0.272 & 8.0 & 4.58 & 36.48 & 84.04 & 11.87 & 3.22 \\
\hline & $92-110$ & 0.57 & 0.07 & 20.94 & 1.369 & 8.1 & 4.55 & 38.40 & 82.52 & 11.14 & 2.20 \\
\hline
\end{tabular}

\section{Conclusion}

The Shirvan plain soils including in the Kur-Araz lowland which is a main agricultural province in Azerbaijan are widely used under different agricultural plants (cotton, grain, grape and etc.) by applying intensive irrigative agriculture in connection with possessing of the favorable soil-ecological condition. The main irrigative soils of the zone are grey-meadow, meadow-grey and greybrown. According to the carried out researches, the irri- gative meadow-grey soils possess high fertility on average level, and the diversity subjected to salinization and clayey is met.

\section{REFERENCES}

[1] M. P. Babayev, "Irrigative Soils in the Kur-Araz Lowland and Their Productive Ability," Baku, 1984.

[2] "Morphogenetic Profiles of the Azerbaijan Soils," Baku, 2004. 
[3] Sh. Z. Jafarova, "Biological Activity of the Natural and Cultural Senoz Soils in Eastern Shirvan," Cand. Sci. (Biol.) Dissertation, Baku, 2010.

[4] M. R. Abduyev, "Soils Salinization of the Shirvan Steppe and Measures of the Fight with Them," Baku. Elm., 2012.

[5] "Account of Soil Cover in the Ujar Region," Baku, 2003.

[6] "Account of Soil Cover in the Kurdamir Region," Baku,
2000 .

[7] G. Z. Azizov and A. Guliyev, "Azerbaijan Salinized Soils, Increase of Their Melioration and Fertility," Baku, 1999.

[8] M. A. Ahmadova, "Concentrating as a Main Factor of Degradation of the Meadow-Grey Soils in Mugan Steppe from Azerbaijan," Materials of the Scientific-Practical Conference, Baku, 2002, pp. 277-278. 